\title{
PEMBELAJARAN MENGGUNAKAN AUGMENT REALITY UNTUK ANAK USIA DINI DI INDONESIA
}

\author{
Ailsa Salsabila Cahyaningtyas \\ Teknologi Pendidikan, Fakultas Ilmu Pendidikan, Universitas Negeri Malang \\ ailsa.salsabila.1801216@students.um.ac.id
}

\begin{abstract}
Abstrak: PAUD (Pendidikan Anak Usia Dini) merupakan suatu pusat pendidikan yang dikhususkan untuk anak usia dini dengan tujuan agar anak-anak usia dini dapat mempersiapkan pendidikan ke jenjang yang lebih tinggi. Anak Usia Dini mempunyai karakteristik yaitu suka dengan bermain, mudah bosan dan memiliki rasa keingin tahuan yang tinggi. Sehingga, dalam melaksanakan pembelajaran untuk anak usia dini harus lebih berfariatif. Maka dari itu, dibutuhkan pembelajaran yang menarik dan tidak membosankan salah satunya yaitu menggunkan Augment Reality (AR). Tujuan dari penulisan artikel telaah ini adalah untuk mengetahui efek penggunaan Augmented Reality pada jenjang Pendidikan Anak Usia Dini (PAUD). Dari hasil kegiatan telaah tersebut menyebutkan bahwa dengan menggunakan Augment Reality(AR) siswa lebih termotivasi dan dapat mudah memahami pembelajaran, serta dapat belajar dan bermain menggunakan Augment Reality (AR) sehingga anak usia dini mendapatkan pengalaman belajar secara langsung.
\end{abstract}

Kata kunci: Media Pembelajaran, Anak Usia Dini, Augment Reality (AR), Pengalaman Belajar

\begin{abstract}
PAUD (Early Childhood Education) is an education center that is devoted to early childhood with the aim that early childhood can prepare for education to a higher level. Early Childhood has the characteristics of like to play, easily bored and has a high curiosity. So, in implementing learning for early childhood should be more varied. Therefore, it takes interesting and not boring learning, one of which is using Augment Reality (AR). The purpose of writing this review article is to find out the effects of using Augmented Reality at the Early Childhood Education (PAUD) level. From the results of the study mentioned that by using Augment Reality (AR) students are more motivated and can easily understand learning, and can learn and play using Augment Reality $(A R)$ so that young children get a direct learning experience.
\end{abstract}

Keywords: Learning Media, Early Childhood, Augment Reality (AR), Learning Experiences 


\section{PENDAHULUAN}

Pembelajaran merupakan kegiatan yang dilaksanakan oleh lembaga pendidikan agar para siswa dapat mencapai tujuan pendidikan yang sudah ditetapkan oleh pemerintah. Menurut (AJAR \& PPG, 2010) tujuan pendidikan yaitu untuk mengantar para siswa untuk merubah tingkah lakunya baik intelektual, moral, maupun sosial dengan tujuan anak dapat hidup mandiri sebagai mahluk individu maupun mahluk sosial. Pembelajaran dilakukan diberbagai jenjang salah satunya yaitu jenjang anak usia dini (PAUD).

Pembelajaran yang dilakukan di PAUD sendiri memiliki tujuan yaitu memberdayakan masyarakat setempat agar anak-anak dapat mempersiapkan ke jenjang pendidikan yang lebih tinggi. Menurut (Gunarti \& Muis, 2014), tujuan pembelajaran yang dilakukan di PAUD diantaranya yaitu merangsang keseimbangan, perkembangan dan pertumbuhan jasmani rohani seperti contohnya perkembangan moral dan agama, perkembangan fisik, perkembangan kecerdasan, serta bahasa dan komunikasi. Selain itu, pembelajaran pada anak usia dini, anak-anak diharuskan belajar untuuk menguasai simbol-simbol (kata-kata) dan mampu mengungkapkan pengalamannya walaupun itu tidak logis.

Pembelajaran yang dilakukan di PAUD berbeda dengan pembelajaran yang dilakukan oleh jenjang diatasnya karena, anak usia dini masih belum bisa berfikir secara kompleks dan belum memiliki pikiran yang matang. Menurut (Saurina, 2016) Pada saat ini anak bersifat egosentris, yaitu melihat sesuatu dari dirinya (perception centration), dengan melihat sesuatu dari satu ciri, sedangkan ciri lainnya diabaikan.. Maka dari itu, pada masa ini anak usia dini memiliki perkembangan potensi yang sangat pesat karena potensi yang berkembang pesat ini, (Trianto, 2011) menyebutkan bahwa masa PAUD merupakan masa keemasan. Sehingga, anak pada usia 2-4 tahun memiliki kemampuan untuk mengikuti permainan dan dapat memahami permainan yang diberikan kepada anak tersebut. 
Berdasarkan ciri pembelajaran PAUD

dan karakteristik anak usia dini diatas, maka pendidik harus kreatif dalam mengajar yaitu tidak hanya berbicara dan sekedar membaca buku, pembelajaran yang dilakukan harus lebih interaktif dan berfariatif dengan tujuan agar siswa PAUD dapat lebih mudah memahami materi yang diajarkan serta tidak mudah bosan. Namun kenyataannya pada saat ini guru yang berada di PAUD ia hanya sekedar berbicara maupun membaca buku ataupun hanya sekedar memberi contoh gambar saja dan dampaknya siswa yang berada di PAUD kurang mendapatkan pengalaman belajar secara langsung Alasan guru menggunakan metode yang monoton dalam mengajar dikarenakan kurangnya media pembelajaran atau alat peraga yang memadai. Maka dari itu, dibutuhkan media pembelajaran yang tepat untuk melakukan pembelajaran di PAUD agar pembelajaran di PAUD lebih interaktif dan siswa lebih mudah memahami. Media pembelajaran merupakan Alat, bahan, maupun teknik yang digunkakan agar komunikasi anatara guru dan siswa lebih efektif pada saat melakukan proses pembelajaran (Mahnun, 2012). Salah satu contoh media yang dapat digunakan untuk pembelajaran di PAUD yaitu penggunaan teknologi Augmented Reality (AR). Augment Reality (AR) adalah sebuah teknologi yang memungkinkan untuk melihat sesuatu objek yang maya (tidak bisa dilihat secara langsung) kedalam lingkungan yang nyata. Menurut (Yudiantika et al., 2013) AR juga dapat didefinisikan sebagai sebuah teknologi yang mampu menggabungkan objek 2D maupun 3D kedalam lingkungan yang nyata. Augment Reality (AR) sudah diterapkan diberbagai bidang, seperti didunia kesehatan seperti alat peraga medis (Indrawaty \& Bakhtiar, 2013). Untuk pembelajaran di PAUD penggunaan AR cukup simple dan efektif karena hanya membutuhkan perangkat mobile saja dimana semua orang sekarang pasti mempunyai smartphone. Maka dari itu, tujuan penulisan artikel telaah ini yaitu untuk mencari tahu lebih lanjut bagaimana penggunaan Augment Reality (AR) pada pembelajaran di PAUD. Selain itu, tujuan dari 
penulisan artikel telaah ini untuk mengetahui keefektifan dan dampak pembelajaran Augment Reality (AR) di PAUD. Cara yang dilakukan yaitu dengan membaca jurnal-jurnal atau penelitian yang berkaitan dengan penggunaan Augment Reality (AR) untuk pembelajaran anak usia dini. Ruang lingkup telaah merupakan tujuan/fokus/konsentrasi yang akan dijalankan sehingga tidak melenceng dari area/ruang lingkup yang nantinya akan dikerjakan. Ruang lingkup dari artikel telaah ini yaitu menggunakan pembelajaran augment reality sebagai media pembelajaran bagi kalangan siswa PAUD agar pembelajaran bagi siswa PAUD tidak terlalu mononton dan membosankan karena bagi siswa PAUD pada zaman modern ini belajar dengan metode lama akan terasa tidak menyenangkan sehingga bermainlah merupakan hal yang menyenangkan dan nantinya akan membantu siswa PAUD dalam proses pembelajaran jika mereka tidak merasa bosan. Maka dari itu ruang lingkup pada artikel ini tertuju pada pembelajaran Augment reality sebagai media pembelajaran pada siswa kalangan PAUD.

\section{HASIL}

\subsection{Anak Usia Dini}

\subsubsection{Pengertian Anak Usia Dini} NAEYC (National

Association for The Education Of Young) menyebutkan bahwa anak usia dini adalah anak yang memiliki usia antara 0-8 tahun, yang tercakup dalam program pendidikan di taman kanak-kanak ataupun yang berada pada keluarga (family child care home), serta berada di pendidikan prasekolah baik swasta, maupun negri, TK ataupun SD. Undang Undang Republik Indonesia Nomor 23 Tahun 2003 tentang Sistem Pendidikan Nasional pada Pasal 1 ayat 14 memberikan pendapat bahwa anak usia dini adalah sebuah upaya pembinaan yang ditujukan untuk anak sejak lahir sampai dengan usia enam tahun yang dilakukan dengan cara pemberian rangsangan,pendidikan untuk membantu pertumbuhan dan perkembangan jasmani dan rohani agar anak usia dini tersebut dapat memiliki kesiapan dalam memasuki pendidikan yang lebih lanjut. Sementara itu, UNESCO dengan persetujuan negara-negara anggotanya berpendapat bahwa 
jenjang anak usia dini termasuk pada level 0 atau jenjang prasekolah yaitu anak-anak yang sudah berusia antara 3-5 tahun. Berdasarkan pengertian diatas, dapat disimpulkan bahwa anak usia dini adalah anak yang berada di rentang 3-8 tahun dimana pada umur tersebut dilakukan upaya penddikan dengan memberikan rangsangan yang bertujuan untuk membantu pertumbuhannya dan perkembangan jasmani maupun rohaninya.

\subsubsection{Karakreristik Anak Usia Dini}

Sama dengan pada fase usia lainnya, anak usia dini memiliki karakteristik yang khas berikut ini adalah beberapa karakteristik anak usia dini (Aisyah et al., 2014) yaitu (1) Memiliki Rasa Ingin Tahu yang Besar. Di masa usia dini ini, anak memiliki rasa keingintahuan yang besar terhadap lingkungan disekelilingnya. Hal ini ditunjukkan ketika anak usia dini berumur sekitar 1 tahunan, ia menunjukkan ketertarikan terhadap benda yang berada disekelilingnya dengan meraih dan memakan benda tersebut. Menurut (Yus, 2011) saat anak pada usia 3 hingga 4 tahun, ia memenuhi rasa keingintahuannya tersebut dengan cara membongkar pasang sesuatu, anak tersebut juga aktif atau gemar untuk bertanya walaupun hanya dengan kalimat yang sederhana. Sebagai pendidik, maka harus memfasilitasi rasa keingintahuan dengan memberikan media pembelajaran yang cukup mudah untuk dipahami. Selain itu, pertanyaan yang ditanyakan oleh anak tersebut harus dilayani dengan jawaban yang bijak.

(2) Pribadi yang Unik. Walaupun banyak anak yang memiliki kesamaan dalam pola umum pekembangan, Setiap anak memiliki keunikan masing-masing dalam hal gaya belajar ataupun minat. Keunikan yang terjadi bisa dikarenakan karena dua fakor yang pertama yaitu faktor genetis contohnya seperti ciri fisik anak tersebut serta faktor kedua yaitu faktor lingkungan contohnya dalam hal minat. (EVIANI, n.d.).

(3) Suka Berfantasi dan Berimajinasi (Memiliki Imajinasi yang Tinggi). Menurut penelitian yang dilakukan oleh (AZIZAH, 2018) anak usia dini senang sekali membayangkan bermacam-macam hal yang berbeda jauh dengan kondisi 
nyatanya. Setelah

membayangkannya, biasanya anakanak menceritakan semua hal seakan akan ia mengalaminya sendiri padahal hal tersebut merupakan fantasi ataupun imajinasinya saja. Hal ini dikarenakan anak usia dini belum memisahkan dengan jelas antara kenyataan ataupun hanya sekedar fantasi saja. Fantasi serta imajinasi yang dimiliki seorang anak ini, penting sekali untuk perkembangan kreativitas serta bahasanya. Dalam hal ini, anak usia dini perlu diarahkan agar dapat memisahkan antara realita maupun khayalan. Fantasi yang dimiliki oleh anak tersebut dapat dikembangkan melalui kegiatan seperti contohnya yaitu mendongeng ataupun bercerita.

(4) Masa Paling Potensial Untuk Belajar. Seringkali pada masa anak usia dini disebut dengan masa golden age. Hal ini dikarenakan, pada masa usia dini, anak mengalami perkembangan dan pertumbuhan yang sangat pesat dari segala aspek (Uce, 2017). Salah satu contohnya pada pertumbuhan otak dengan bertambahnhya berat otak. Selain pertumbuhan otak, pada masa usia dini merupakan waktu yang tepat untuk membangun motoric anak. Maka dari itu, seorang pendidik dalam mengajar anak usia dini perlu memberikan berbagai stimulasi dengan tepat agar masa keemasan ini tidak terlewatkan begitu saja akan tetapi diisi dengan berbagai hal yang dapat mengoptimalkan tumbuh kembang anak.

(5) Memiliki Sikap Egosenteis yang Tinggi. Egosentris berasal dari kata ego yang artinya aku dan sentris yang artinya pusat. dalam artian, anak usia dini dalam memahami segala sesuatu hanya dari sudut pandang tersendiri, bukan dari sudut pandang orang lain (Pitalokasari, 2013). Sifat egosentris pada anak usia dini seperti contohnya yaitu ketika anak berebut mainan, menangis atau merengek ketika permintaannya tidak dituruti, menganggap ayah atau ibunya merupakan orang tuanya saja bukan orang tua dari adik atau kakaknya.

(6) Memiliki Daya Konstentasi Dalam yang Pendek. Maksud dari memiliki daya konsentrasi yang pendek yaitu anak usia dini memiliki perhatian yang mudah teralihkan dengan aktivitas maupun kegiatan 
lain. Hal ini dapat terjadi ketika anak tersebut merasa bahwa kegiatan yang dilakukan sebelumnya tidak menarik baginya lagi. Menurut (Habsari \& Syukri, n.d.) bahwa rentang konsentrasi anak usia dini dalam memperhatikan sesuatu berlangsung hanya 5-10 menit kecuali hal tersebut bisa membuatnya senang. Maka dari itu, sebagai seorang pendidik haruslah berusaha membuat susasana yang menyenangkan dalam mendidik anak usia dini.

(7) Merupakan Bagian Dari Mahluk Sosial. Salah satu karakteristik anak usia dini yaitu anak usia dini suka bergaul maupun bermain dengan teman sebayanya. Dalam hal ini, anak usia dini mulai belajar berbagi, mengalah ataupun antri dalam menunggu gilirannya bermain pada saat ia bersama temantemannya. Menurut dengan melakukan interaksi bersama teman sebayanya anak dapat membentuk konsep dirinya (Nurmalitasari, 2015). Melalui interaksi sosial anak juga belajar bersosialisasi dan belajar untuk bisa diterima di lingkungannya. Anak dapat belajar berperilaku sesuai dengan harapan sosialnya karena dalam kehidupan sehari-hari ia masih membutuhkan orang lain.

\subsection{Media Pembelajaran}

\subsubsection{Pengertian}

Media

\section{Pembelajaran}

Media telah mempengaruhi seluruh aspek kehidupan, meskipun dalam derajat yang berbeda-beda (Umar, 2017). Media pemebelajaran awalnya berasal dari kata "Media" berasal dari Bahasa latin yang merupakan bentuk jamak dari kata "Medium", secara harfiah arti kata tersebut adalah perantara atau pengantar, penghubung antara orang yang memberikan informasi dengan yang menerima informasi. Menurut (Lee et al., 2012) media adalah alat ataupun sarana yang berfungsi sebagai perantara antara komunikator dan komunikan. Berdasarkan uraian diatas, pengertian media adalah sesuatu yang digunakan sebagai perantara dalam memberikan informasi antara komunikator dan komunikan.

Menurut UU Republik Indonesia No 20 Tahun 2003 tentang system pendidikan nasional, bahawa pembelajaran adalah proses interaksi pserta didik dengan pendidik dan 
sumber belajar pada suatu lingkungan belajar. Jadi dapat disimpulkan bahwa media pembelajaran adalah sebuah perantara yang digunakan untuk memberikan informasi antara komunikator dan komunikan (pembelajar dan peseta didik) dalam melakukan kegiatan proses belajar mengajar. Menurut (Susilana et al., 2008) media pembelajaran adalah sebuah alat, metode, ataupun teknik yang digunakan oleh guru dalam rangka mengefesienkan komunikasi dan interaksi antara guru dan siswa dalam proses pengajaran disekolah yang bertujuan untuk mencapai tujuan pendidikan yang sudah ditentukan oleh pemerintah. Lebih singkatnya, media pembelajaran adalah alat yang digunakan oleh guru sebagai perantara dalam melakukan pembelajaran guna memepermudah untuk mencapai infotmasi agar tujuan pendidikan yang telah ditetapkan pemerintah dapat tercapai.

\subsubsection{Kegunaan Media}

\section{Pembelajaran}

Menurut (Emda, 2011) media pembelajaran memiliki manfaat diantaranya yaitu : (1) mengubah titik berat pendidikan formal, yang artinya adalah dengan media pembelajaran yang awalnya merupakan pembelajaran yang abstrak menjadi pembelajaran yang kongkrit. Selain itu, pembelajaran yang awalnya menjadi teoristis menjadi pembelajaran yang fungsional dan praktis. (2) Membangkitkan motivasi belajar. yang dimaksud dalam hal ini adalah media pembelajaran menjadi motivasi eksternal atau motivasi ekstrinsik bagi pebelajar atau peserta didik. Hal ini dikarenakanb penggunaan media pembelajaran menjadikan titik perhatian atau perhatian yang menarik sehingga pebelajar atau peserta didik terpusat perhatiannya pada saat melakukan pembelajaran. (3) Memberikan kejelasan. Fungsi media pembelajaran dalam hal ini pengetahuan dan pengalaman pebelajar atau peserta didik lebih mudah dimengerti maka peranan media pembelajaran adalah memperjelas hal tersebut.(4) Memberikan stimulasi belajar, peran media pembelajaran dapat meningkatkan rasa ingin tahu pebelajar atau peseerta didik karena media pembelajaran dapat 
merangsang untuk selalu timbul dipuaskan,.

Derek Rowntree dalam bukunya yangn berjudul "Educational Technology in Curiculum Development" mengutamakan enam fungsi media pembelajaran diantaranya yaitu :

Membangkitkan motivasi pebelajar atau peserta didik. (2) Mengulang apa yang telah dipelajari (3) Menyediakan stimulus belajar (4) Menyediakan umpan balik dengan segera (5) Menggalakkan latihan yang serasi dan (6) Mengaktifkan respon murid. Media pembelajaran memiliki keistimewaan didalamnya. (Suartama, 2010) mengemukakan tiga keistimewaan media pembelajaran diantaranya yaitu (1) Keistimewaan fiksatif adalah kemampuan sebuah media pembelajaran untuk menangkap, menyimpan, dan kemudian menampilkan kembali suatu objek atau kejadian. Dengan kemampuan ini, dapat memungkinkan suatu objek akan dipotret, digambar ataupun direkam, lalu kemudian disimpan pada saat yang dipelukan untuk dapat ditampilkan dan diamati kembali. (2)
Keistimewaan manipulatife adalah kemampuan untuk menampilkan kembali sebuah objek maupun kejadian dengan berbagai macam cara sesuai dengan keperluan. Yang dimaksud hal ini adalah sebuah objek ataupun suatu kejadian tersebut ditampilkannya secara berulangulang dengan perubahan ukuran, kecepatan, serta dapat diulang-ulang penampilannya. (3) Keistimewaan distributif adalah dalam sekali penampilan sebuah objek maupun kejadian dapat menjangkau pengamat yang sangat besar jumlahnya dan tersebar didalam kawasan yang sangat luas. Contohnya seperti penggunaan televisi, radio dan surat kabar.

\subsubsection{Kerucut Pengalaman Edgar} Dale

dalam penggunaan media pembelajaran adalah yaitu bagaimana media pembelajaran tersebut dapat digunakan oleh guru atau pendidik sehingga proses pembelajaran yang ada didalamnya menjadi menyenangkan, dan tidak terkesan membosankan. Pembelajaran yang menyenangkan dan tidak 
membosankan ini dapat terjadi ketika media pembelajaran yang digunakan oleh guru atau pendidik merupakan media pembelajaran yang baru, Dimana, media pembelajaran tersebut belum pernah diketahui oleh siswa ataupun peserta didik baik dari segi tampilan fisiknya maupun tampilan yang non fisik. Selain kedua hal tersebut, isi pesan yang disampaikan dalam media pembelajaran tersebut hendaknya juga merupakan sesuatu hal yang baru dan atraktif, contohnya adalah dari segi warna maupun desain dari media pembelajaran tersebut (Muhson, 2010).

Terkait dengan hal tersebut, seorang ilmuan yang bernama Edgar Dale mengelompokkan atau mengklasifikasikan pengalaman belajar menjadi beberapa tingkatan. Dalam tingkatan tersebut, terdapat hal mulai dari yang paling konkrit menuju hal yang paling abstrak. Pengklasifikasian atau pengelompokan tersebut yang biasanya saat ini dikenal dengan kerucut pengalaman Edgar Dale (Cone Of Experience). Didalam teori kerucut pengalaman Edgar Dale tersebut, diberitahukan bahwa pengalaman belajar yang akan dperoleh sisa atau peserta didik bisa diproses melalui perbuatan ataupun peserta didik tersebut mengalami sendiri materi yang telah diajarkan tersebut, proses mengamati dan mendengarkan melalui tertentu ataupun proses mendengarkan melalui media audio (Dale, 1997).

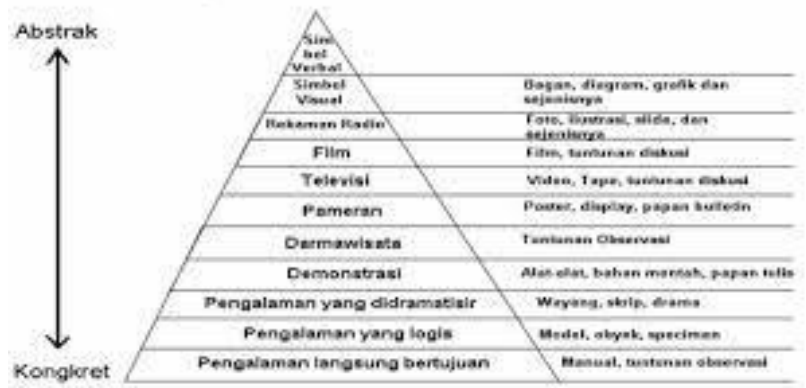

Teori kerucut pengalaman Edgar Dale tersusun dari yang paling bawah atau yang paling kongkrit serta dari yang paling atas ataupun yang paling abstrak. Teori tersebut memberitahukan bahwa pengalaman belajar yang diperoleh oleh peserta didik ataupun siswa bisa melalui perbuatan atau mengalami sendiri apa yang dipelajari oleh siswa tersebut secara langsung, proses mengamati serta mendengarkan melalui media pembelajaran tertentu serta proses mendengarkan melalui Bahasa. Dari teori kerucut pengalaman Edgar Dale 
tersebut, dapat disimpulkan bahwa semakin nyata pengalaman yang diperoleh oleh peserta didik ataupun siswa dalam mempelajari sebuah pengajaran seperti contohnya pengalaman langsung, maka semakin banyaklah pengalaman yang diperoleh siswa sehingga dapat dengan mudah memahami materi pelajaran dan mengingatnya dalam jangka waktu yang panjang. Namun, sebaliknya jika semkain abstrak pengalaman yang dilakukan oleh siswa seperti contohnya hanya melalui membaca saja atau mendengarkan Bahasa verbal, maka siswa akan semakin sedikit memperoleh pengalaman belajar terseut dan siswa pun akan semakin sulit memahami pembelajaran yang dilakukan dan hanya dapat mengingatnya dalam memori jangka pendek.

\subsection{Augment Reality}

\subsubsection{Pengertian Augment Reality}

Inovasi perkembangan

teknologi yang saat ini berkembang dan digunakan dalam membangun alat peraga sebagai penunjang Kegiatan Belajar Menagajar (KBM) yaitu Augment Reality (AR).
Pengertian dari Augment Realitu (AR) sendiri adalah penggabungan antar objek virtual dengan objek yang nyata (Akçayır \& Akçayır, 2017). Seperti contohnya pada saat pembawa acara televisi membacakan sebuah berita, terdapat animasi atapun objek virtual yang ikut bersama pembawa berita tersebut jadi seperti yang dilihat seolah olah objek tersebut bersama dan ada didalam pembawa berita acara tersebut padahal, objek yang terlihat merupakan objek maya dan merupakan hasil dari teknik penggabungan antara dunia nyata dan dunia maya. (Efendi, 2017) mengakatakan bahwa Augmented reality adalah sebuah teknologi yang mengubungkan dunia maya kedalam dunia nyata yang diproyeksikan didalam dunia nayata dengan menggunakan bantuan berbagai perangkat seperti contohnya webcam, komputer, HP Android, maupun menggunakan bantuan kacamata khusus.

Menurut (Andriyadi，2011) pada saat ini, penggunaan Augmented Reality (AR) sudah diterapkan diberbagai bidang keilmuan seperti contohnya yaitu : (1) Bidang 
kedokeran. Dibidang kedokteran

Reality sudah digunakan dalam hal contoh penggunaan Augmented Reality yaitu simulasi untuk operasi, simulasi pembuatan vaksin virus, dll. (2) Hiburan atau Entertaiment. Bentuk penggunaan Augmented Reality dalam bidang hiburan atau Entertaiment sangatlah beragam ada yang dimanfaatkan untuk efek perfilman, permainan untuk smartphone, penggunaan untuk majalah dll. (3) Latihan Militer atau militer training, Dibidang militer sendiri sudah digunakan pada saat latihan tempur untuk membuat suatu permainan perang dimana seorang prajurit masuk kedalam dunia game tersebut. (4) Enginering. Didalam bidang engineering sendiri pemanfaatan Augmented Reality dalam melakukan berbagai eksperimennya. Contohnya Enginering mesin dalam memperbaiki mobil yang rusak. (5) Robotics dan Telerobotics didalam bidang robotika, orang yang membuat robot tersebut memerlukan bantuan Augmented Reality (AR) dalam menggunakan pencitraan visual dalam mengendalikan robot tersebut.

(6) Consumer Design. Augmented mempromosikan produk seperti contohnya pengembangan brosur virtual yang digunakan memberikan informasi secara lengkap secara 3D sehingga customer atau pelanggan dapat mengetahui dengan jelas produk yang akan ditawarkan.

\subsubsection{Penggunaan Augmented} Reality Untuk Pembelajaran PAUD

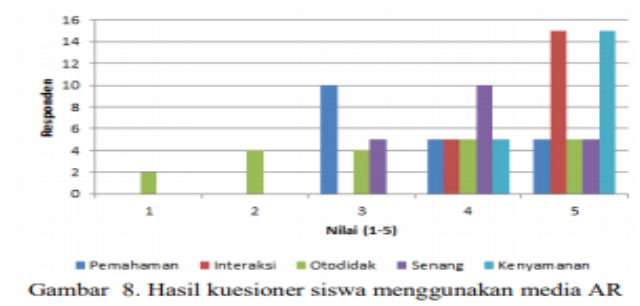

Selain digunakan dalam berbagai bidang seperti yang sudah dijelaskan diatas, penggunaan Augmented Reality (AR) juga memiliki mafaat didalam dunia pendidikan. Penggunaan Augmented Reality (AR) didalam dunia pendidikan contohnya adalah digunakan sebagai media pembelajaran yang memanfaatkan teknologi. Karena penggunaan yang praktis dan simple penggunaan Augmented Reality sudah diterapkan diberbagai mata pelajaran dari bermacam macam jenjang mulai dari jenjang Sekolah 
Dasar hingga Sekolah Menengah Atas atau bahkan diigunakan untuk pembelajaran diperguruan tinggi. Menurut (Perdana et al., 2012) kelebihan menggunakan Augmented Reality ini dapat membantu dalam menyampaikan sebuah informasi kepada pengguna atau peserta didik.

$$
\text { Hal ini dikarenakan }
$$

Augmented Reality (AR) merupakan media pembelajaran yang interaktiif, realtime karena menggunakan objek 3

Dimensi. (Apriyani \& Gustianto, 2015) juga menyebutkan bahwa penggunaan media pembelajaran Augmented Reality memakan biaya yang lebih murah dibandingkan dengan Virtual Reality. Didalam pembelajaran tingkat PAUD, Augmented Reality sudah banyak digunakan untuk membantu pembelajaran. Seperti contohnya penelitian yang dilakukan oleh (Indriani et al., 2016) yang memanfaatkan teknologi Augmented Reality unutk pembelajaran di PAUD mengatakan bahawa pembelajaran dengan menggunakan Augmented Reality dapat meningkatkan partisipasi atau keaktifan anak tersebut dalam melakkan pembelajaran. Sedangkan penelitian yang dilakukan oleh (Senduk \& Karouw, 2016) pembelajaran menggunakan Augmeneted Reality di PAUD dapat menimbulkan rasa keingin tahuan peserta didik tersebut sehingga peserta didik yang ada di PAUD tidak merasa bosan dan penelitian yang dilakukan juga menyebutkan bahwa, penggunaan Augmented Reality dapat meningkatkan pemahaman siswa didalam pembelajaran tersbut dibandingkan menggunakan media pembelajaran yang hanya berupa gambar.

\section{KESIMPULAN}

Berdasarkan hasil telaah diatas dapat disimpulkan bahwa Augmented Reality cocok digunakan untuk melakukan pembelajaran yang ada di PAUD. Hal ini dikarenakan pembelajaran menggunakan Augmented Reality mampu membuat siswa mengalami pembelajaran secara langsung. Berdasarkan teori pengalaman kerucut Edgar Dale bahwa semakin nyata pengalaman belajar yang dialami oleh siswa maka ia akan dapat lebih mudah memahami 
pembelajaran tesebut dan dapat menyimpannya kedalam memori jangka panjang. Selain dapat memeudahkan peserta didik atau siswa daalam memahami materi pembelajran, penggunaan Augmented Reality dapat meningkatkan motivasi belajar peserta didik karena Augmented Realuty sendiri merupakan media pembelajaran yang termasuk baru dan jarang dilihat ataupun digunakan oleh anak usia dini.

Sehingga, pada saat digunakan peserta didik akan penasaran dengan hal baru tersebut seperti yang disebutkan bahwa peserta didik mempunyai karakteristik yaitu mudah tertarik dengan sesuatu hal yang baru atau memiliki rasa keingintahuan yang sangat tinggi. Jika peserta didik memiliki rasa keingintahuan yang tinggi dalam melakukan proses pembelajaran, maka pembelajaran tersembut menjadi tidak monton dan menjadi pembelajaran yang aktif dan interaktif. Selain dari sisi peserta didik, penggunaan Augmented Reality juga menguntungkan bagi pendidik atau guru pada sekolah PAUD tersebut. Karena penggnaan
Augmented Reality yang mudah dan tidak membutuhkan biaya yang besar. Guru pun bisa lebih efektif dalam melakukan persiapan sebelum mengajar. Penggunaan Augmented Realitu selain dari segi penggunaan yang mudah, Augmented Reality juga memudahkan guru dalam menyampaikan informasi kepada peserta didiknya seperti kegunaan media pembelajaran yang sudah dijelaskan diatas.

\section{UCAPAN TERIMA KASIH}

Dengan selesainya artikel telaah ini, saya mengucapkan Terima Kasih kepada Tuhan Yang Maha Esa karena atas Karunia dan RahmatNya saya dapat menyelesaikan artikel ini. Tak lupa, saya sampaikan Terima Kasih kepada Bapak Ence Surahman, S.Pd, M.Pd dan Ibu Dra. Susilaningsih, M.Pd. selaku pembimbing mata kuliah Karya Tulis Ilmiah Teknologi Pendidikan yang telah membantu, mengajarkan serta membei masukan dan saran terhadap artikel telaah yang telah saya buat sehingga saya dapat menyelesaikan artikel telaah ini. 


\section{DAFTAR PUSTAKA}

Aisyah, S., Amini, M., Chandrawati,

T., \& Novita, D. (2014).

Perkembangan dan konsep dasar pengembangan anak usia dini.

AJAR, B., \& PPG, P. P. G. (2010). Media pembelajaran anak usia dini.

Akçayır, M., \& Akçayır, G. (2017). Advantages and challenges associated with augmented reality for education: A systematic review of the literature. Educational Research Review, 20, $1-11$.

Andriyadi, A. (2011). Augmented reality with ARToolkit. Bandar Lampung: Augmented Reality Team.

Apriyani, M. E., \& Gustianto, R. (2015). Augmented Reality sebagai Alat Pengenalan Hewan Purbakala dengan Animasi 3D menggunakan Metode Single Marker. Jurnal Infotel, 7(1), 4752.

AZIZAH， I. N. U. R. (2018). PENGARUH PERMAINAN LEMPAR BOLA TERHADAP KEMAMPUAN MOTORIK KASAR ANAK USIA 4-6 TAHUN DI TK MARDISIWI KEPUHREJO.

Dale, E. (1997). Media Pembelajaran. Tersedia: http://bagawanabiyasa. wordpress. com/2013/05/26/media ....

Efendi, I. (2017). Pengertian Augmented Reality (AR). IT Jurnal, Https://Www. It-Jurnal. Com/Pengertian-AugmentedRealityar, 17.

Emda, A. (2011). Pemanfaatan media dalam pembelajaran biologi di sekolah. JURNAL ILMIAH DIDAKTIKA: Media Ilmiah 
Pendidikan Dan Pengajaran, 12(1), 149-162.

EVIANI, D. (n.d.). laporan pengabdian: MENEMUKENALI ANAK DENGAN HAMBATAN PERILAKU PADA USIA DINI (PAUD ISLAM TERPADU BINTANG QUR'ANI BANJARMASIN).

Gunarti, W., \& Muis, A. (2014). Metode Pengembangan Perilaku dan Kemampuan Dasar AUD.

Habsari, D., \& Syukri, M. (n.d.). Metode Pengenalan Konsep Bilangan Pada Anak Kelompok Umur 4-5 Tahun Di Tk. Jurnal Pendidikan Dan Pembelajaran Khatulistiwa, 2(1).

Indrawaty, Y., \& Bakhtiar, M. Y. (2013). Implementasi Model Skenario Petri Net Pada Multimedia Interaktif Pembelajaran Kimia. Jurnal
Informatika, 4(1), 48-56.

Indriani, R., Sugiarto, B., \& Purwanto, A. (2016). Pembuatan Augmented Reality Tentang Pengenalan Hewan untuk Anak Usia Dini Berbasis Android Menggunakan Metode Image Tracking Vuforia. SEMNASTEKNOMEDIA

ONLINE, 4(1), 4-7.

Lee, J., Lin, L., \& Robertson, T. (2012). The impact of media multitasking on learning. Learning, Media and Technology, 37(1), 94-104.

Mahnun, N. (2012). Media pembelajaran (kajian terhadap langkah-langkah pemilihan media dan implementasinya dalam pembelajaran). An-Nida', 37(1), 27-34.

Muhson, A. (2010). Pengembangan media pembelajaran berbasis teknologi informasi. Jurnal Pendidikan Akuntansi Indonesia, 
$8(2)$.

Nurmalitasari,

F. (2015)

Perkembangan sosial emosi pada anak usia prasekolah. Buletin Psikologi, 23(2), 103-111.

Perdana, M. Y., Fitrisia, Y., \& Putra, Y. E. (2012). Aplikasi Augmented Reality Pembelajaran Organ Pernapasan Manusia Pada Smartphone Android. Jurnal Aksara Komputer Terapan, 1(1).

Pitalokasari, I. (2013). Pengelolaan kelas PAUD dalam meningkatkan disiplin belajar peserta didik di TK Siwijaya Ringinarum Kendal. IAIN Walisongo.

Saurina, N. (2016). Pengembangan Media Pembelajaran Untuk Anak Usia Dini Menggunakan Augmented Reality. Jurnal IPTEK, 20(1), 95-108.

Senduk, E. P., \& Karouw, S. (2016). MLearning Pendidikan Karakter untuk Anak Usia Dini Berbasis Augmented Reality. Jurnal Teknik Informatika, 9(1).

Suartama, I. K. (2010). Pengembangan mutimedia untuk meningkatkan kualitas pembelajaran pada mata kuliah media pembelajaran. Jurnal Pendidikan Dan Pengajaran, 43(3).

Susilana, R., Si, M., \& Riyana, C. (2008). Media pembelajaran: hakikat, pengembangan, pemanfaatan, dan penilaian. $\mathrm{CV}$. Wacana Prima.

Trianto, I. B. A. (2011). Desain Pengembangan Pembelajaran Tematik Bagi Anak Usia Dini TK/RA \& Anak Kelas Awal SD/MI Edisi Pertama. Jakarta: Kencana. Uce, L. (2017). The golden age: Masa efektif merancang kualitas anak. Bunayya: Jurnal Pendidikan Anak, 1(2), 77-92. 
Umar, U. (2017). MEDIA PENDIDIKAN: Peran dan Fungsinya dalam Pembelajaran. Tarbawiyah Jurnal Ilmiah Pendidikan, 11(01), 131-144.

Yudiantika, A. R., Pasinggi, E. S., Sari, I. P., \& Hantono, B. S. (2013). Implementasi Augmented Reality Di Museum: Studi Awal Perancangan Aplikasi Edukasi Untuk Pengunjung Museum. Yogyakarta: Konferensi Nasional Teknologi Informasi Dan Komunikasi (KNASTIK), Fakultas Teknologi Informasi, Universitas Kristen Duta Wacana.

Yus, A. (2011). Model pendidikan anak usia dini. Kencana. 